\section{IJ§ER}

ISSN: 2149-5939
International Journal of Social Sciences and Education Research

Online, http://dergipark.gov.tr/ijsser

Volume: 3(1), 2017

\title{
Öğretmen adaylarının matematik öğretiminde oyunların kullanımı ile ilgili görüşleri ${ }^{1,2}$
}

\author{
The opinions of pre-service teachers on the usage of games in mathematics teaching
}

\author{
Neslihan Usta ${ }^{3}$, Ayşe Derya Işık ${ }^{4}$, Gülsün Şahan ${ }^{5}$, Süreyya Genç ${ }^{6}$, Fatih Taş ${ }^{7}$, Gonca Gü- \\ lay $^{8}$, Fatma Diril ${ }^{9}$, Özge Demir ${ }^{10}$, Kazım Küçüik ${ }^{11}$
}

\begin{abstract}
Received Date: 02 / 09 / 2016
Accepted Date: 25 / 12 / 2016

$\ddot{O} z$

Bu çalışmanın amacı, öğretmen adaylarının matematik öğretiminde oyunların kullanımı ile ilgili görüşlerini ortaya çıkarmaktır. Bu çalıșmanın katılımcılarını Batı Karadeniz Bölgesi'nin bir ilinde bulunan bir devlet üniversitesinin İlköğretim Matematik Öğretmenliği Bölümü'nde ögrenim gören 7 dördüncü sinıf ögrencisi oluşturmaktadır. Öğretmen adayları iki yıl süre ile Ortaokul Matematik Dersi Öğretim Programı (2013)'nda yer alan çeșitli konularla ilgili oyunlar hazırlamışlardır. Bu oyunlar bir devlet okulunun 7. sinıfinda öğrenim gören öğrencilere 2015-2016 eğitim ögretim yılında 2 ay boyunca uygulanmıştır. Uygulamalar sonunda öğretmen adaylarının matematik ögretiminde oyunların kullanımı ile ilgili görüşleri alınmıştır. Çalışmada nitel yaklaşım esas alınmıştır. Bu çalışmada nitel araştırma yaklaşımına dayalı durum çalışması yöntemi kullanılmıştır. Veri toplama aracı olarak 7 açık uçlu sorudan oluşan yarı yapılandırılmış görüsme formu kullanılmıștır. Görüșme formunda öğretmen adaylarına oyunlarla matematik ögretimi hakkındaki düşünceleri, oyun hazırlarken karşılaştıkları güçlükler ve ögretmen olduklarında matematik derslerinde oyunları kullanıp kullanmayacaklarına ilișkin düsüncelerini içeren sorular sorulmuștur. Bu çalıșmanın bulguları, ögretmen adayları ile yapılan yarı-yapılandırılmış görüşmelerden elde edilmiştir. Verilerin analizi nitel veri analiz tekniklerinden içerik analizi ile yapılmıştır. Çalışma sonucunda, öğretmen adayları oyunların hazırlanmasında çeşitli zorluklar (ögretim programında yer alan her konuya, her kazanıma uygun oyun hazırlamada, oyunun kurallarının oluşturulmasında, günlük hayatta oynanan bir oyunu sınıf seviyesine uygun hale getirmede, gerekli ögretim materyallerini hazırlamada vb.) yașadıklarını belirtmişlerdir. Ayrıca çalıșmada öğretmen adaylarının matematik derslerinde oyunların kullanılmasının gerekli ve yararlı olduğunu, matematik dersine olan korkunun ĕ̆lenceli bir ögrenme ortamında azaltılabileceğini ve bu sayede matematik dersini daha somut ve anlașılır bir hale getireceğini düşündükleri belirlenmiştir.
\end{abstract}

Anahtar sözcükler: Matematik öğretimi, oyunlar, öğretmen adaylarl, görüşler

\begin{abstract}
The aim of this study is to analyse the opinions of pre-service teachers on the usage of games in mathematics teaching. The participants of this study consist of 7 fourth-grade students studying at the Primary Mathematics Teaching Department of a state university in a province in the Western Black Sea region. The pre-service teachers prepared games related to certain subjects included in the Secondary School Mathematics Curriculum (2013) for a period of two years and these games were applied to the students studying in 7th grade of a public school. The qualitative approach was taken as a basis in the study. An interview form consisting of 7 open-ended questions was used as a data collection tool. In the interview form, the pre-service teachers were asked about their opinions on mathematics teaching with games, the difficulties they encountered while preparing games and whether they would use games during mathematics lessons when they became teachers. The findings of this study were obtained
\end{abstract}

\footnotetext{
${ }^{1} \mathrm{Bu}$ çalışma, 2014-2016 yılları arasında Bilimsel Araştırma Projesi kapsamında gerçekleştirilen projenin bir bölümünü içermektedir. Bu çalışma, Bartın Üniversitesi Bilimsel Araştırma Projeleri Komisyonu tarafindan desteklenmiştir (Proje No:2014-SOS-A-006)./ This study includes a part of the project conducted within the context of the Scientific Research Project between the years of 20142016. This study was supported by Bartın University, Scientific Research Project Commission (Project No: 2014-SOS-A-006). ${ }^{2}$ Bu çalıșma, "2. Uluslararası Sosyal Bilimler ve Eğitim Konferansı'nda" sunulan bildirinin genişletilmiş halidir (İstanbul, 2016). ${ }^{3}$ Bartın Üniversitesi, Bartın, Türkiye, neslihanusta74@gmail.com, ${ }^{4}$ Bartın Üniversitesi, Bartın, Türkiye, aysederya@bartin.edu.tr. ${ }^{5}$ Bartın Üniversitesi, Bartın, Türkiye, gsahan@ bartin.edu.tr, ${ }^{6}$ Bartın Üniversitesi, Bartın, Türkiye, sgenc@ bartin.edu.tr. ${ }^{7}$ Bartın Üniversitesi, Bartın, Türkiye, fatihtas @ bartin.edu.tr, ${ }^{8}$ Yüksek Lisans Öğrencisi, MEB, Bartın, Türkiye, gncgly@gmail.com, ${ }^{9}$ Yüksek Lisans Öğrencisi, MEB, Bartın, Türkiye, ftm.drl.01@gmail.com, ${ }^{10}$ Yüksek Lisans Öğrencisi, MEB, Bartın, Türkiye, ozgegokkurt51@ hotmail.com, ${ }^{11}$ Yüksek Lisans Öğrencisi, MEB, Bartın, Türkiye, kzmkck28@gmail.com,
} 
Usta, N., ve Diğerleri (2017). The opinions of pre-service teachers on the usage of games in mathematics teaching. International Journal of Social Sciences and Education Research, 3(1), 328-344.

from the semi-structured interviews with pre-service teachers. The analysis of the data was conducted with the content analysis which is one of the qualitative data analysis techniques. At the end of the study, pre-service teachers stated that they had some difficulties in preparing games (finding a game suitable for each learning outcome and each subject in the curriculum, creating rules of the game, adaptation of a game played in daily life to the class level, preparing necessary teaching materials, etc). Moreover, it is identified in the study that pre-service teachers think that the use of games in mathematics lessons is necessary and useful, the fear for mathematics lessons can be reduced in a fun learning environment and thus mathematics lessons can become more concrete and comprehensible.

Keywords: Mathematics teaching, games, pre-service teachers, opinions

\section{Giriș}

Matematik, ilkokuldan üniversiteye kadar çoğu öğrenci tarafından başarılması zor bir ders olarak görülmektedir. Bu durumun nedenlerinden bazıları yapılan pek çok çalışmada gösterildiği gibi öğrencilerde matematik dersine karşı olan korku ve kaygıdır. Uğurel ve Moralı (2008)'ya göre, öğrencilerin matematiğe karşı yanlış bakış açısı matematiğin günlük hayatta dört işlemden başka ne işe yaradığı ve nerelerde kullanıldığına ilişkin sorular yöneltmelerine neden olmaktadır. Öğrencilerdeki matematiğe karşı olan korku, kaygı ve önyargıların yok edilerek matematiğe olumlu tutum geliştirmiş bireylerin yetiştirilmesi önemlidir. Aktif öğrenme yaklaşımı, öğrenciyi merkeze alan, öğrencilerin aktif olduğu ve öğrenme sorumluluklarını kendilerinin aldığı yaklaşımlardan biridir (Köroğlu, Yeşildere, 2002). Aktif öğrenme, öğrencilerin ne yaptıklarının ve nasıl yaptıklarının farkında olmalarını sağlayan bir öğrenme yaklaşımı olarak tanımlanmaktadır (Prince, 2004). Bu yaklaşımın yöntemlerinden biri olan oyunla öğretim yöntemi son y1llarda matematik öğretiminde kullanılmaya başlamıştır (Özgenç, 2010). Özgenç (2010)'e göre, bunun nedeni matematik eğitimcilerinin, oyunlarla öğretimin matematik eğitiminin amaçlarını gerçekleştirmek için uygun olduğunu görmeleri olmuştur. bu bağlamda günümüz öğretim yöntemlerinden biri oyunlarla öğretim yöntemidir. Araştırmalar oyunla öğretimin başarı, motivasyon ve performansın artmasında olumlu etkilerinin olduğunu göstermektedir (Randel \& Morris, 1992).

Matematiksel yeterliklerin kazandırılmasında, öğrencilerde matematiğe karşı olumlu tutumun geliştirilmesinde (Soylu, 2001'den akt. Tural, 2005) matematik dersinin somutlaştırılmasında ve kavramların kazandırılmasında ( Altunay, 2004) oyunlarla öğretim etkili bir yöntemdir. Matematik öğretiminde oyunlar yararlı aktivitelerden biri olarak kabul edilmektedir (Lovitt \& Clarke, 1988, akt. Lee, 2008). Foster'e göre, "Öğrencileri, matematik etkinlikleri içine almanın en iyi yolu, oyunlarla kendi dünyaları arasında bağ kurmalarını sağlamaktır" ( akt. Uluçay ve Çakır, 2004). Oyunu, Bilen (1989) bireylerin fiziksel ve zihinsel yeteneklerini geliştirici, sanatsal ve estetik nitelikler taşıyan ve yaşamı zevkli kılan etkinlikler olarak tanımlarken, Demirel (1994) ise sınıf içinde oynanan oyunların öğrenilen bilgilerin pekiştirilmesini ve rahat bir ortamda tekrarlanmasını sağlayan etkinlikler olarak tanımlamaktadır (akt. Pehlivan, 1997). Oyun eğlendirirken eğiten ve öğreten etkinliklerdir (Pehlivan, 1997). Tural (2005)'a göre oyun, öğrencinin öğrenme ortamında isteyerek ve zevk alarak katıldığı, eğitsel değer taşıyan, öğretimin amaçlarına göre planlanmış, kendine özgü kuralları olan ve özel malzeme gerektiren bireysel veya grupla yapılan etkinliklerin tamamıdır. Oyunlar, kuramsal öğrenme ile uygulama arasında soyut yaşantıları somuta indirgemesiyle önemli bir bağ kurar (Scmitz ve diğ. 2003, akt. Özgenç, 2010). Bu bağlamda öğretmenler, öğrencilerin öğrenmeyi kolaylaştırıcı ve ilgi çekici bir ortamda öğrencileri motive edecek ve öğrenmelerine yardımcı olacak öğretim ortamları oluşturmaya çalışmalıdır (Malone, 1980). Oyunlar eğlenceli ve motive edici ortamların oluşturulmasında önemli bulunmaktadır. 
Usta, N., ve Diğerleri (2017). Öğretmen adaylarının matematik öğretiminde oyunların kullanımı ile ilgili görüşleri. International Journal of Social Sciences and Education Research, 3(1), 328-344.

Oyunlar öğrencilerin yaşlarına, anlamalarına ve etkin katılımlarına olanak sağlayacak şekilde hazırlanmalı ve süreç öğretmen tarafından kontrol altında tutulmalıdır (Şaşmaz Ören \& Erduran Avc1, 2004). Oyunla öğretim yöntemi farklı öğrenme stillerine sahip öğrencilere uygun öğrenme firsatları sunduğundan öğrenciyi deste aktif hale getirerek matematik dersine karşı öğrencide olumlu tutumun gelişmesine katkıda bulunmaktadır (Katmada, Mavridis, \& Tsiatso, 2014; Tural, 2005; Tural Sönmez, 2012).

Oyunla öğretim sürecinde oyunların birden fazla duyu organına hitap etmesi, somut materyallerle hazırlanması ve öğrenciler arasındaki iletişimi teşvik etmesi önemlidir (Kaya \& Elgün, 2015). Öğrenciler oyun oynarken yeni fikirler üretebilir ve üst düzeyde bir performans gösterebilir (Seo, 2003, akt. Kaya \& Elgün, 2015). Charles, Bustard ve Black (2009)'a göre, öğrenme ortamına katılım arttıkça başarı da artmaktadır. Aktif katılımın sağlanmasının en iyi yollarından bir eğitsel oyunları kullanmaktır. Öğrenme sürecinde oyunların kullanılmasının en önemli faydalarından biri öğretim hedefleri ile bütünlük sağlayarak eğlenceli bir ders ortamının sağlanmasıdır (Hays, 2005).

Kaya ve Elgün (2015) çalışmalarında uyguladıkları eğitsel oyunların öğrencilerin zihinsel ve fiziksel olarak derse aktif katılımlarını sağladığını, Şaşmaz Ören ve Erduran Avc1 (2004) ise deney grubundaki öğrencilerin kontrol grubundaki öğrencilere göre derse karşı ilgilerinde olumlu yönde değişimlerin olduğunu belirtmektedirler. Gelen ve Özer (2010) çalışmalarında oyunlaştırma yöntemi ile işlenen derslerde öğrencilerin matematik dersine karşı tutumlarının ve problem çözme başarılarının arttığını tespit etmişlerdir. Benzer şekilde Tural (2005) ve Tural Sönmez (2012) tarafından yapılan çalışmalarda oyun ve etkinliklerle öğretimin matematik dersine karş1 ilgisiz ve kaygılı öğrencilerin derse karşı ilgi, tutum ve heyecanlarında olumlu değişimlerin meydana gelmesinde büyük katkıları olduğu ifade edilmektedir. Tural (2005), ilköğretim matematik öğretiminde oyun ve etkinliklerle öğretimin geleneksel öğretime göre, öğrencilerin erişimleri ve matematik dersine ilişkin tutumlarında deney grubu lehine anlamlı farklar bulduğunu ifade etmiştir.

Aksoy ve Kaleli Yılmaz (2011), altıncı sınıf öğrencilerine kesirler konusunun oyun destekli öğretimi ile öğrencilerin matematiğe yönelik tutumlarındaki gelişimlerinin kontrol grubundaki öğrencilere göre deney grubundaki öğrencilerin daha yüksek olduğunu tespit etmişlerdir.

Köroğlu ve Yeşildere (2002), oyunla öğretimi yedinci sınıfta yer alan bazı matematik konularına yönelik oyunlar ve senaryolar geliştirerek uygulamışlardır. Yazarlar uygulama sırasında öğrencilerin çok dikkatli bir şekilde ders dinlediklerini, gönüllü olarak derse katılmak istediklerini ve zihinsel olarak aktif olduklarını gözlemlediklerini belirtmişlerdir. Ayrıca öğrencilere uyguladıkları anket verilerine göre, matematiğe karşı güdülen olumsuz yargıya rağmen öğrencilerin oyunlar ve etkinliklerle matematik eğitimini cazip bulduklarını ifade ettiklerini belirtmişlerdir. Duran ve Kaplan (2014), ilköğretim sekizinci sınıf öğrencileri ile 'Kelimeden Kavrama' oyununa ilişkin öğrenci-öğretmen görüşlerini değerlendirmişlerdir. Araştırma sonuçlarına öğrencilerin çoğu oyun hakkında olumlu görüş belirtmiş ve oyunun yararlı olduğunu ifade etmiştir.

Tural (2005)'a göre oyun ve etkinliklerle öğretimin matematik dersinin hedeflerine ulaşmada etkin ve işlevsel bir yöntem olmasıyla öğrencilerin erişi düzeylerinde ve derse olan tutumlarında etkili olmasının bazı nedenleri bulunmaktadır. Tural (2005)'ın ifade ettiği nedenler arasında oyunların öğrenme ortamını somut, görsel ve işitsel pek çok materyal ile zenginleştirmesi, dersi zevkli 
Usta, N., ve Diğerleri (2017). The opinions of pre-service teachers on the usage of games in mathematics teaching. International Journal of Social Sciences and Education Research, 3(1), 328-344.

ve eğlenceli hale getirmesi, derse ve konuya ilginin sürekliliğini sağlaması, sınıfta disiplin sorunlarını en aza indirmesi, öğrencilerin aktif hale gelmesini sağlaması ve öğrenciler arasındaki iletişimi arttırması yer almaktadır. Öğrenciler üzerinde yapılan oyunla öğretim çalışmalarının yanı sıra bu yöntemle ilgili olarak öğretmenler ve öğretmen adaylarının görüşlerinin değerlendirildiği çalışmalar da bulunmaktadır.

Özgenç (2010)'in, çalışmasının sonuçlarına göre, oyun temelli etkinlikler öğrencilerin derse ilgisini ve katılımını olumlu yönde etkilemekte ve öğrenci-öğrenci ve öğrenci-öğretmen etkileşimini arttırmaktadır. Özgenç (2010) bu sonuçlara göre öğretmen öğrencilerin geleneksel rollerinin değiştiğini ifade etmektedir.

Uğurel (2003) öğretmen adaylarının ve öğretmenlerin matematik öğretiminde oyun ve etkinliklerin kullanılmasına ilişkin görüşlerini değerlendirdiği çalışmasında oyunlarla öğretimin öğrencilerde derse karşı ilgiyi arttırdığı 1 ve motivasyonu sağladığı, öğrencilerin dersi eğlenerek öğrendiği, bilgilerin kalıcı ve hızlı öğrenilmesine imkân sağladığı, ezberleme alışkanlığını azalttığı, öğrencilerin derslerde aktif olmaları nedeniyle öğrenmeye karşı isteklerinin arttığı, öğrencilerin kendi aralarında ve öğrenci öğretmen arasında sağlıklı iletişim kurulmasını sağladığı gibi pek çok avantajının olduğuna yönelik ortak görüşleri tespit etmiştir. Uğurel (2003) çalışmasında öğretmenlerin ve öğretmen adaylarının bütün bu olumlu düşüncelerine rağmen oyun ve etkinliklerden yeterli derecede yararlanamamalarının gerekçelerini ise öğretmenlerin ve öğretmen adaylarının görüşlerine göre açıklamaktadır. Bunlar; konu hakknda bilgi sahibi olmama, uygulanan matematik programının çok yoğun olmast ve bu nedenle ögretimde farklı aktivitelere yeterince zaman ayrılmaması, ÖSS'nin ögrretimde doğurduğu olumsuzluklar ve okulların sosyal ve fiziki yapılarinda var olan yetersizlikler olarak siralanmaktadır.

Güneş (2010), matematik öğretmenlerinin görüşlerini değerlendirdiği çalışmasında, öğretmenlerin oyun ve etkinlikler sayesinde öğrencilerin matematiğe karşı olumlu tutum geliştirdiklerini, konu ve kavramlara yönelik olarak hazırlanan oyun ve etkinliklerin öğrencileri olumlu yönde güdülediğini düşündüklerini belirtmiştir. Ayrıca çalışmaya katılan öğretmenler, öğrencilerden dönüt almada oyun ve etkinliklerin kolaylık sağlayabileceği fikrine sahip olduklarını ifade etmiştir. Ancak, öğretmenlerin oyun ve etkinliklerin matematik öğretiminde etkili bir yöntem olduğunu düşünmelerine karşın büyük bir kısmı matematikte yer alan bütün konularda oyunların ve etkinliklerin kullanımlarının elverişli olmayacağını ve etkinliklerin öğrencilerle birlikte hazırlanmasının daha etkili olacağını düşündüklerini ifade etmektedir. Güneş (2010) çalışmasında ayrıca öğretmenlere göre, oyunlar ve etkinlikler derse hazırlık sırasında dikkat çekmek ve güdülemek amacıyla kullanılmasının uygun olacağını ifade ettiklerini belirtmektedir. Çalışmada öğretmenlerin çoğu, oyunlarla öğretim yapılmasının öğretmenlerin tecrübesizliğinin oyun ve etkinliklerin kullanımını zorlaştıracağına, oyunlarla öğretimin ögretmen otoritesini zayıflatacă̆ına, sınıf yönetiminde çeşitli zorluklar yaşatabileceğine, oyun ve etkinliklerin ekonomik olarak bir yük getireceğine, ögretmene planlama ve uygulamada fazladan sorumluluk yükleyeceğine ve sinıf mevcutlarının fazla olmasının oyun ve etkinliğin kullanımını olumsuz yönde etkileyebileceğine ilişkin bazı olumsuzlukları da beraberinde getirebileceğine inandıkları da ifade edilmektedir (Güneş, 2010). Bu çalışmada ilköğretim matematik öğretmeni adaylarının matematik öğretiminde oyunların kullanımı ile ilgili görüşleri incelenmektedir. Literatür incelendiğinde ortaöğretimde öğretmen adaylarının ve öğretmenlerin (Uğurel, 2003) ve ilköğretim ikinci kademe öğretmenlerinin (Güneş, 2010) matematik öğretiminde oyun ve etkinliklerin kullanımına ilişkin görüşlerini inceleyen ça- 
Usta, N., ve Diğerleri (2017). Öğretmen adaylarının matematik öğretiminde oyunların kullanımı ile ilgili görüşleri. International Journal of Social Sciences and Education Research, 3(1), 328-344.

lışmalara rastlanmaktadır. Ancak İlköğretim matematik öğretmen adaylarının matematik öğretiminde oyunların kullanımı ile ilgili görüşlerini inceleyen çalışmalara pek rastlanamamıştır. Bu doğrultuda çalışmada öğretmen adaylarının matematik öğretiminde oyunların kullanımı ile ilgili görüşlerinin incelenmesi amaçlanmıştır.

\section{Yöntem}

\subsection{Araştırma modeli}

$\mathrm{Bu}$ çalışmada nitel araştırma yaklaşımına dayalı durum çalışması yöntemi kullanılmıştır. Nitel durum çalışmaları bir ya da birkaç durumu bütüncül bir yaklaşımla derinlemesine araştıran çalışmalardır. Bu çalışmalarda duruma ilişkin etkenlerin ilgili durumu nasıl etkiledikleri ve durumdan nasıl etkilendikleri incelenir (Yıldırım, Şimşek, 2008,77). Bu çalışmada öğretmen adaylarının oyunların matematik öğretiminde kullanımına ilişkin görüşleri detaylı olarak incelendiğinden bu yöntemin kullanılması uygun görülmüştür.

\section{2. Çalışma grubu}

Bu çalışmanın katılımcılarını Batı Karadeniz Bölgesi'nin bir ilinde bulunan bir devlet üniversitesinin İlköğretim Matematik Öğretmenliği Bölümü’nde öğrenim gören 7 dördüncü sınıf öğrencisi oluşturmaktadır. Öğretmen adayları iki dönem boyunca lisans dersi olan “Özel Öğretim Yöntemleri I”, Özel Öğretim Yöntemleri II” ve yüksek lisans dersi olan “Oyunlarla Matematik Öğretimi” derslerini almışlardır. Öğretmen adayları iki yıl süre ile Ortaokul Matematik Dersi Öğretim Programı (2013)'nda yer alan çeşitli konularla ilgili oyunlar hazırlamışlardır. Yüzdeler, doğrular ve açılar, çokgenler ve çember ve daire konuları ile ilgili hazırlanan oyunlar bir devlet okulunun 7. sınıfında öğrenim gören öğrencilere yüksek lisansa devam eden ders öğretmeni ve öğretmen adayları ile birlikte 2015-2016 eğitim öğretim yılında 2 ay boyunca uygulanmıştır. Uygulamalar sonunda öğretmen adaylarının matematik öğretiminde oyunların kullanımı ile ilgili görüşleri alınmıştır. Araştırmada öğretmen adaylarının gerçek isimleri yerine kız öğrenciler için $\mathrm{K}$ ve erkek öğrenciler için $\mathrm{E}$ olmak üzere $\mathrm{K}_{1}, \mathrm{~K}_{2}, \mathrm{~K}_{3}, \mathrm{~K}_{4}, \mathrm{E}_{5}, \mathrm{E}_{6}$ ve $\mathrm{E}_{7}$ şeklinde kodlar verilmiştir.

\subsection{Verilerin toplanması}

Veri toplama aracı olarak araştırmacılar tarafından uzman görüşleri doğrultusunda hazırlanan7 açık uçlu sorudan oluşan yarı yapılandırılmış görüşme formu kullanılmıştır. Görüşme formunda öğretmen adaylarına oyunlarla matematik öğretimi hakkındaki düşünceleri, oyun hazırlarken karşılaştıkları güçlükler ve zorlanıp zorlanmadıkları zorlandı iseler hangi konularda zorlandıkları, öğretim programında yer alan bütün konularda oyunla öğretimin yapılıp yapılamayacağı, ortaokulda her sınıf seviyesinde bu yöntemin uygulanıp uygulanmayacağı, oyunla öğretimin olumsuz taraflarının olup olmadığı varsa neler olduğu sorulmuştur. Ayrıca öğretmen adaylarına öğretmen olduklarında oyunla öğretimi matematik derslerinde kullanmayı düşünüp düşünmedikleri ve son olarak uygulama ile ilgili olarak eklemek istedikleri olup olmadığı sorulmuştur.

\subsection{Verilerin analizi}

Verilerin analizi nitel veri analiz tekniklerinden içerik analizi ile yapılmıştır. İçerik analizinde, toplanan verileri açıklayacak kavramlara ve ilişkilere ulaşmak temel amaçtır. Betimsel yaklaşımla fark edilmeyen kavram ve temalara içerik analizi ile ulaş1labilir. Bunun için veriler kavramsallaştırılır, mantıklı şekilde düzenlenir ve veriyi açılayan temalar saptanır (Yıldırım \& Şimşek, 2008, 
Usta, N., ve Diğerleri (2017). The opinions of pre-service teachers on the usage of games in mathematics teaching. International Journal of Social Sciences and Education Research, 3(1), 328-344.

227). Bu çalışmadan elde edilen veriler araştırmacılar tarafından kategori ve alt kategorilere ayrılmış ve kodlama yüzdesi \% 85 olarak bulunmuştur. Fark için araştırmacılar bir araya gelerek uzlaşmaya varmışlardır.

\section{Bulgular}

Bu bölümde öğretmen adaylarının yazılı açıklamalarının analizinden elde edilen bulgulara yer verilmektedir.

Tablo 1. Öğretmen adaylarının oyunlarla matematik öğretimi hakkındaki düşüncelerine ilişkin görüşler

\begin{tabular}{|c|c|c|c|}
\hline Kategori & Alt Kategori & ÖAK & Örnek Açıklamalar \\
\hline \multirow{12}{*}{ 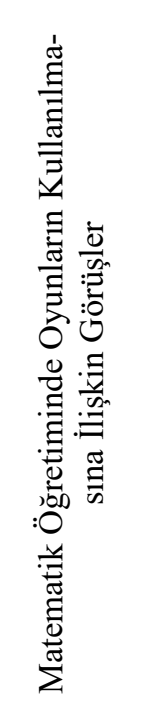 } & & \multirow{11}{*}{$\begin{array}{l}\mathrm{K}_{1} \\
\mathrm{~K}_{2} \\
\mathrm{~K}_{3} \\
\mathrm{~K}_{4} \\
\mathrm{E}_{5} \\
\mathrm{E}_{6} \\
\mathrm{E}_{7}\end{array}$} & "Türkiye genelinde matematiğe karşı bir ön yargı mevcut öğ- \\
\hline & & & rencilerin çoğu kolaylıkla yapabileceği konuları yapamam \\
\hline & & & düşüncesiyle yaklaşarak konuları gerçekten yapamıyorlar. \\
\hline & & & Bu projede ögrenilmesinde zorluk yaşanan konular eğlenceli \\
\hline & & & hale getirilerek en kalıcı öğrenmelerin să̆landığını düşünü- \\
\hline & & & yorum." $\left(E_{6}\right)$ \\
\hline & & & "Geleneksel yöntemlerle matematik ögretim artık ögrenci- \\
\hline & & & lere çok sıkıcı gelmeye başladı. Zaten mevcut yöntemlerle \\
\hline & Olumlu Görüş & & ögrencilerin kaygı düzeyleri daha da artmaktadır. Bu sebep- \\
\hline & & & geleceğine inantyorum. Ögrenciler oyunlarla matematiği sl- \\
\hline & & & $\begin{array}{l}\text { kılmadan, zevk alarak ögreneceklerine inanıyorum." }\left(E_{5}\right) \\
\text { “...̈̈zellikle matematik dersine olan ön yarglların giderilme- } \\
\text { sini sağlayarak sevilen bir ders olmasına yarar sağlar. Bun- } \\
\text { dan dolayı matematik eğitiminde oyunun kesinlikle kullanıl- } \\
\text { ması gerektiğini düşünüyorum. Kullanırken de ögrenci sevi- } \\
\text { yesini ve ilgileri de dikkate almalıyı.” }\left(K_{2}\right)\end{array}$ \\
\hline & Olumsuz Görüş & - & - \\
\hline
\end{tabular}

ÖAK: Öğretmen Adayının Kodu

Öğretmen adaylarına matematik derslerinde oyunların kullanılmasına ilişkin görüşlerinin sorulduğu ve örnek açıklamaların verildiği Tablo 1'de adayların herhangi olumsuz bir görüş belirtmediği görülmektedir. Öğretmen adaylarının görüşleri değerlendirildiğinde beş adayın $\left(\mathrm{K}_{2}, \mathrm{~K}_{3}, \mathrm{~K}_{4}, \mathrm{E}_{5}, \mathrm{E}_{6}\right)$ oyunlarla matematik öğretiminin matematik dersini daha zevkli ve eğlenceli hale getirdiğini, dört adayın $\left(\mathrm{K}_{1}, \mathrm{~K}_{3}, \mathrm{E}_{5}, \mathrm{E}_{6}\right)$ matematik dersine ilişkin öğrencilerde zaten var olan önyargıyı yıkmaya yardımcı olacağını ve bu sayede matematik dersinin öğrenilmesine ilişkin öğrencilerde korku ve kaygının azalacağını $\left(\mathrm{K}_{4}, \mathrm{E}_{5}\right)$ ifade etmişlerdir. $\mathrm{K}_{2}$ ve $\mathrm{E}_{6}$ oyunlarla matematik öğretiminin etkili ve kalıcı bir öğretim olduğunu, $\mathrm{K}_{4}$ öğrencilerin matematiği daha rahat öğrenebileceklerini keşfetmelerini sağladığını ve öğrencilerin konunun içine girmesiyle yaşayarak-eğlenerek öğrenmelerinden dolayı daha kalıcı bilgiler edinebileceklerini belirtmişlerdir. Ayrıca $\mathrm{K}_{1}$ dersin öğretiminde oyunların öğrencilerin derse daha iyi motive olmalarını sağladığını, $E_{7}$ ise öğrencilerin aktif olmalarını sağlayarak dersin sıkıcı ve monoton geçmesini engellediğini ifade etmektedir. $\mathrm{E}_{7}$ oyunların matematik dersinin somut ve daha anlaşı1ır olmasını sağladığını da belirtmiş̧ir.

Genel olarak değerlendirildiğinde öğretmen adayları matematik derslerinde oyunların kullanılmasının gerekli ve yararlı olduğunu düşünmektedir. Matematik dersine olan korku ve kaygının giderilerek önyargının azaltılmasıyla eğlenceli bir ortamda öğretim yapılmasının öğrencilerde daha kalıcı öğrenmeler meydana getireceğini ve matematik dersinin daha somut ve anlaşılır olmasını sağlayacağını ifade etmişlerdir. 
Usta, N., ve Diğerleri (2017). Öğretmen adaylarının matematik öğretiminde oyunların kullanımı ile ilgili görüşleri. International Journal of Social Sciences and Education Research, 3(1), 328-344.

Tablo 2. Öğretmen adaylarının oyun hazırlarken güçlük yaşama durumuna ilişkin görüşleri

\begin{tabular}{|c|c|c|c|}
\hline Kategori & Alt Kategori & ÖAK & Örnek Açılamalar \\
\hline \multirow[t]{2}{*}{ 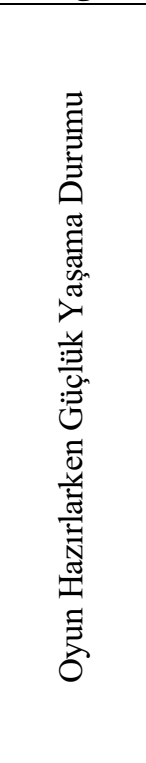 } & Güçlük Yaşama & $\begin{array}{l}\mathrm{K}_{1}, \\
\mathrm{~K}_{2}, \\
\mathrm{~K}_{3}, \\
\mathrm{~K}_{4}, \\
\mathrm{E}_{5}, \\
\mathrm{E}_{6}, \\
\mathrm{E}_{7}\end{array}$ & 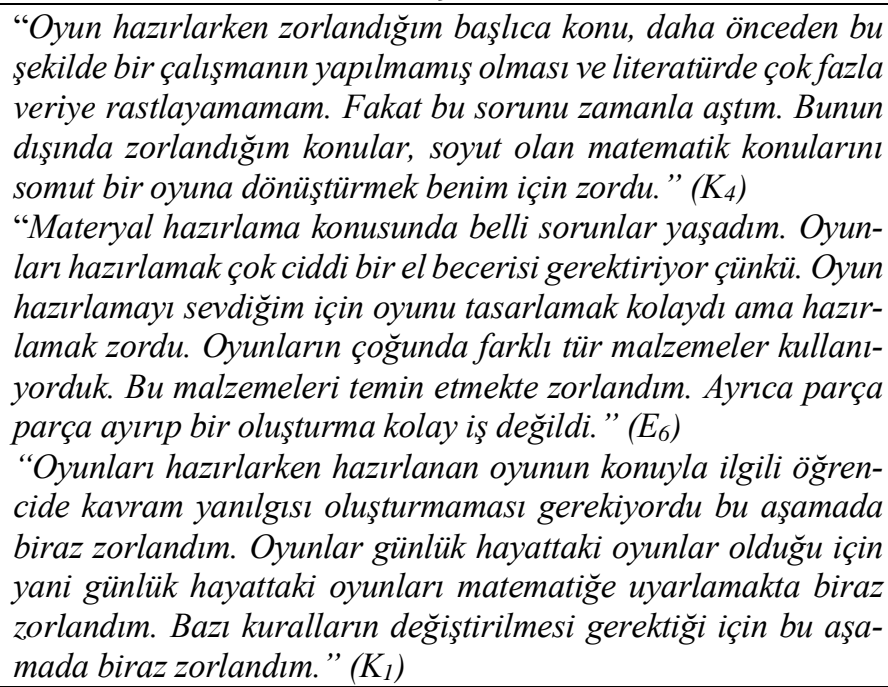 \\
\hline & $\begin{array}{l}\text { Güçlük Yaşa- } \\
\text { mama }\end{array}$ & - & e \\
\hline
\end{tabular}

ÖAK: Öğretmen Adayının Kodu

İkinci soruda matematik öğretmeni adaylarına matematik derslerinde kullanılacak oyunları hazırlama sırasında herhangi bir güçlük yaşayıp yaşamadıkları sorulmuştur. Devamında adaylardan eğer bir güçlükle karşılaştılarsa bu güçlüklerin neler olduğunu açıklamaları istenmiştir. Tablo 2 'den de görüldüğü gibi çalışmaya katılan tüm öğretmen adayları oyunların hazırlanması sırasında çeşitli güçlükler yaşadıklarını ifade etmişlerdir. Öğretmen adaylarının görüşleri değerlendirildiğinde, dört adayın $\left(\mathrm{K}_{2}, \mathrm{~K}_{3}, \mathrm{E}_{5}, \mathrm{E}_{7}\right)$ oyunları sınıf seviyesine uygun şekilde hazırlamanın, üç aday $\left(\mathrm{K}_{2}, \mathrm{E}_{5}, \mathrm{E}_{7}\right)$ Ortaokul Matematik Dersi Öğretim Programı (2013)'ndaki her konuya ya da her kazanıma uygun bir oyun hazırlamanın zor olduğunu belirtmişlerdir. Ayrıca bazı öğretmen adayları günlük hayattaki oyunları matematiğe uyarlamada $\left(\mathrm{K}_{1}, \mathrm{~K}_{4}\right)$ oyunun kurallarını oluşturmada $\left(\mathrm{K}_{1}, \mathrm{~K}_{3}, \mathrm{E}_{7}\right)$ ve özgün oyun hazırlamada $\left(\mathrm{K}_{2}\right)$ zorlandıklarını belirtmişlerdir. $\mathrm{E}_{5}$ oyun hazırlamanın oldukça vakit aldığını ve düşündüğü bazı oyunlarla konuyu bağdaştırmada zorlandığını, $\mathrm{E}_{6}$ ise oyunda kullanılacak olan materyallerin hazırlanmasında el becerisi gerektirdiğinden dolayı zorlandığını belirtmiştir.

Genel olarak bir değerlendirme yapıldığında oyunların hazırlanmasında öğretmen adaylarının bazı sıkıntılar yaşadıkları; bunların başında her konuya, her kazanıma uygun oyun hazırlamada, oyunun kurallarının oluşturulmasında, günlük hayatta oynanan bir oyunu sınıf seviyesine uygun hale getirmede ve gerekli öğretim materyallerini hazırlanmada zorlandıkları anlaşılmaktadır.

Üçüncü soruda öğretmen adaylarına öğretmen olduklarında matematik derslerinde oyunları kullanmayı düşünüp düşünmedikleri sorulmuş ve gerekçelerini açıklamalanı istenmiştir. Örnek açıklamalar Tablo 3'te verilmektedir. Beş aday $\left(\mathrm{K}_{2}, \mathrm{~K}_{4}, \mathrm{E}_{5}, \mathrm{E}_{6}, \mathrm{E}_{7}\right)$ öğretmen olduklarında oyunları derslerinde kesinlikle kullanacaklarını belirtirken, iki aday $\left(\mathrm{K}_{1}, \mathrm{~K}_{3}\right)$ kısmen kullanacaklarını belirtmişlerdir. Adaylar öğretmen olduklarında matematik dersinde oyunları kullanmak istemesinin gerekçesini öğretmekte zorluk yaşayabileceğini düşündüğü konuların mantığını oturtmakta çok yararlı olacağını düşünmesi $\left(\mathrm{E}_{6}\right)$ olarak açıklamıştır. Diğer bir aday ise gerekçeyi bu çalışma sırasında çok emek vererek hazırladığı oyunların matematik öğretiminde kullanıldığında gerçekten faydalı olaca- 
Usta, N., ve Diğerleri (2017). The opinions of pre-service teachers on the usage of games in mathematics teaching. International Journal of Social Sciences and Education Research, 3(1), 328-344.

ğına inandığı ve eğlendirerek öğretmeyi benimsemesi $\left(E_{5}\right)$ olarak açıklamıştır. Oyunları kısmen kullanmayı düşünen adaylar $\left(\mathrm{K}_{1}, \mathrm{~K}_{3}\right)$ ise her derste oyunu kullanmama gerekçelerini sürekli oyunlarla öğretim yapıldığında öğrencilerin sıkılabileceklerini düşünmeleri ve ders saatinin kısıtlı olması olarak göstermişlerdir. Bu adaylar anlatım yönteminin sıkıcı hale geldiği durumlarda, öğrencileri derse motive etmenin zor olduğu durumlarda etkin katılım sağlamak için, dersin başlangıcında ve öğretiminde zorlanılan konuların öğretilmesinde kullanabileceklerini ifade etmiş̧lerdir.

Tablo 3. Öğretmen adaylarının matematik öğretiminde oyunları kullanma durumuna ilişkin görüşleri

\begin{tabular}{|c|c|c|c|}
\hline Kategori & Alt Kategori & ÖAK & Örnek Açıklamalar \\
\hline \multirow[t]{2}{*}{ 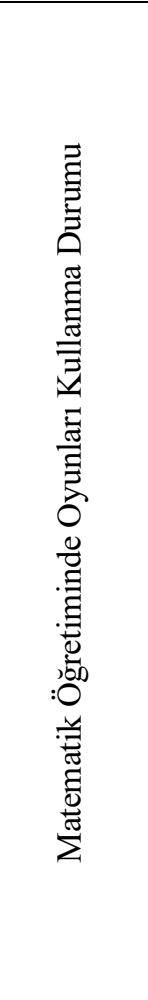 } & $\begin{array}{c}\text { Oyunları Kul- } \\
\text { lanma }\end{array}$ & $\begin{array}{l}\mathrm{K}_{1}, \\
\mathrm{~K}_{2}, \\
\mathrm{~K}_{3}, \\
\mathrm{~K}_{4}, \\
\mathrm{E}_{5}, \\
\mathrm{E}_{6}, \\
\mathrm{E}_{7}\end{array}$ & 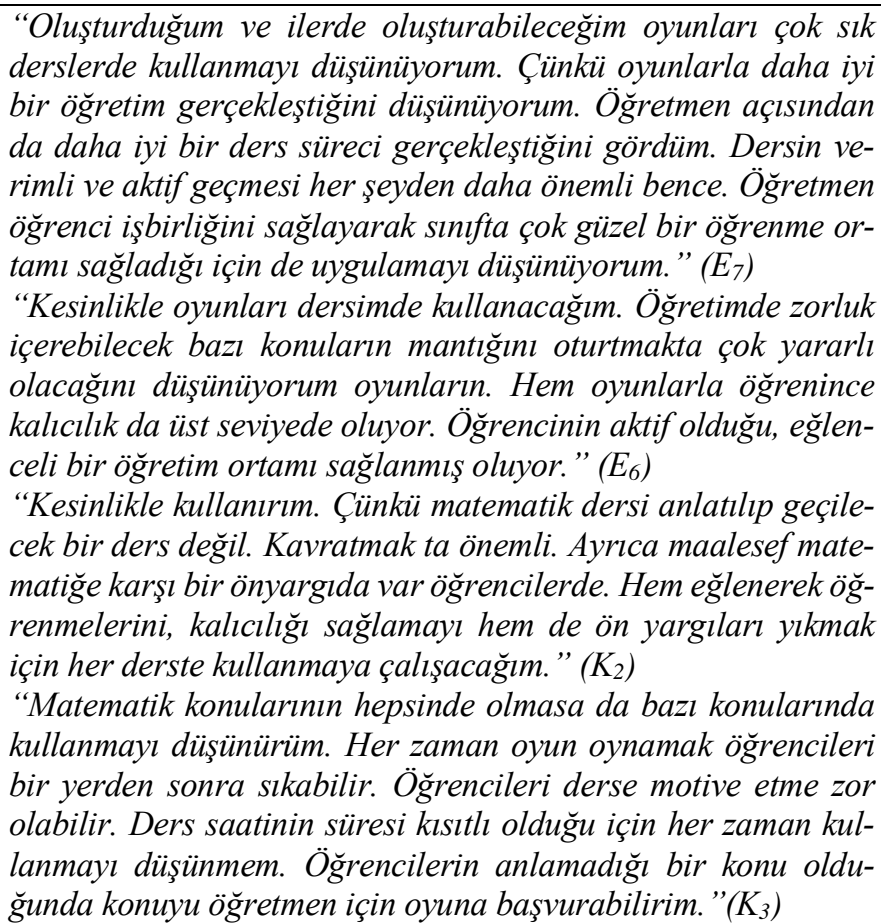 \\
\hline & $\begin{array}{c}\text { Oyunları Kullan- } \\
\text { mama }\end{array}$ & - & 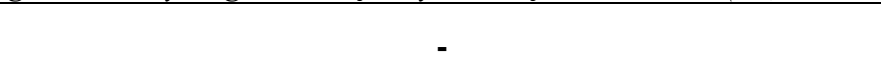 \\
\hline
\end{tabular}

ÖAK: Öğretmen Adayının Kodu

Açıklamalar genel olarak değerlendirildiğinde öğretmen adaylarının oyunların matematik dersini daha eğlenceli, zevkli ve anlaşılır hale getirdiğini düşündükleri ortaya çıkmaktadır. Ayrıca öğretmen adayları oyun tabanlı bir ders ortamının öğrenciler için daha verimli bir öğrenme ortamı oluşturacağını düşündükleri için matematik derslerinde oyunları kullanmak istediklerini ifade etmektedirler.

Dördüncü soruda öğretmen adaylarına oyunların matematik derslerinde uygulanması sırasında herhangi bir güçlük yaşayıp yaşamadıkları sorulmuş ve eğer yaşadılarsa bu güçlüklerin neler olduğu konusunda açıklama yapmaları istenmiştir. Örnek açıklamaların verildiği Tablo 4'te $\mathrm{E}_{7}$ dışındaki öğretmen adayları uygulamada bazı güçlükler yaşadıklarını dile getirdikleri görülmektedir. Yaşanan sorunlarla ilgili olarak bulgular değerlendirildiğinde üç adayın $\left(\mathrm{K}_{1}, \mathrm{~K}_{2}, \mathrm{~K}_{4}\right)$ uygulama yapılan öğrencilerin ilk uygulamalarda oyunlara adapte olamadıklarını fakat uygulamaların artması ve zamanın geçmesiyle bu zorluğun aşıldığını belirtmişlerdir. İki aday $\left(\mathrm{K}_{4}, \mathrm{E}_{6}\right)$ uygulama sırasında sınıfın kontrolünü sağlamakta zorlandıklarını ve iki aday da $\left(\mathrm{K}_{4}, \mathrm{E}_{5}\right)$ oyun için ders süresinin yeterli olmamasından dolayı zorlandıklarını ifade etmişlerdir. Oyunların bazı öğrencilerin ilgisini çekmemesi 
Usta, N., ve Diğerleri (2017). Öğretmen adaylarının matematik öğretiminde oyunların kullanımı ile ilgili görüşleri. International Journal of Social Sciences and Education Research, 3(1), 328-344.

$\left(\mathrm{K}_{2}\right)$ ve oyunları dersin bir parçası olarak görmemelerinden dolayı derse karşı ilgisiz olmaları $\left(\mathrm{E}_{5}\right)$ adayların yaşadıklarını ifade ettikleri diğer güçlüklerdir.

Tablo 4. Öğretmen adaylarının matematik öğretiminde oyunları uygulamada güçlük yaşama durumuna ilişkin görüşleri

\begin{tabular}{|c|c|c|c|}
\hline Kategori & Alt Kategori & ÖAK & Örnek Açıklamalar \\
\hline 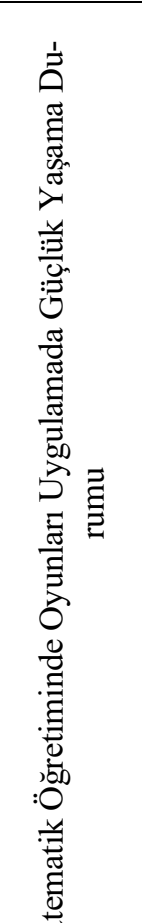 & Güçlük Yaşama & $\begin{array}{l}\mathrm{K}_{1}, \\
\mathrm{~K}_{2}, \\
\mathrm{~K}_{3}, \\
\mathrm{~K}_{4}, \\
\mathrm{E}_{5}, \\
\mathrm{E}_{6}\end{array}$ & 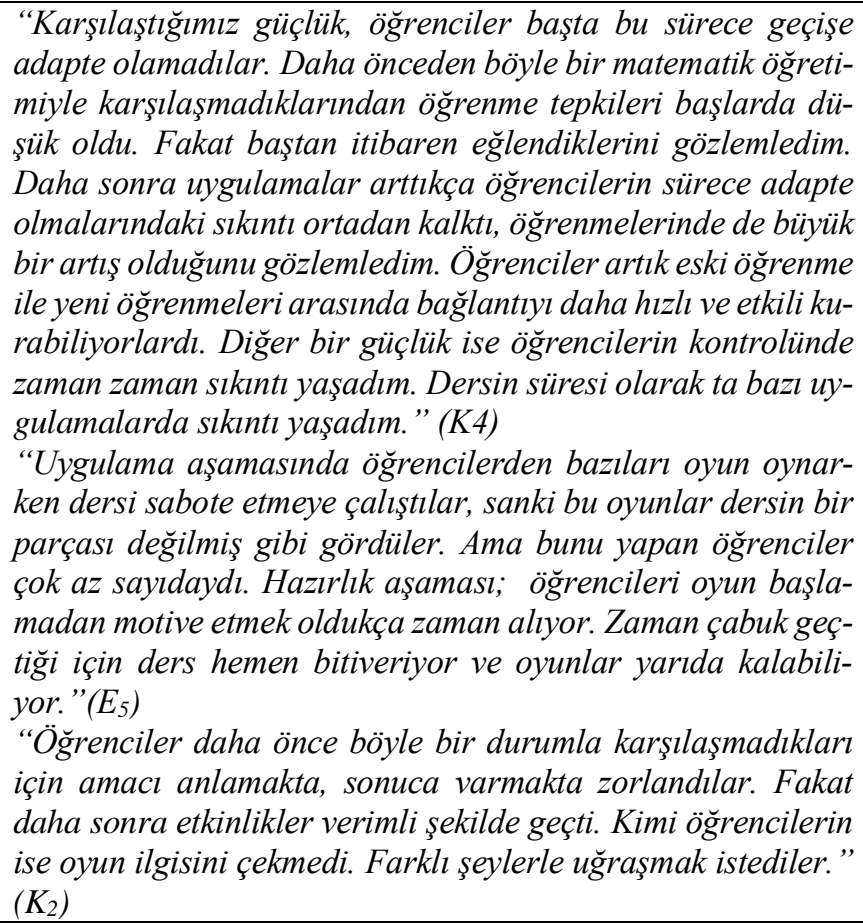 \\
\hline$\sum^{\pi}$ & Güçlük Yaşamama & $\mathrm{E}_{7}$ & 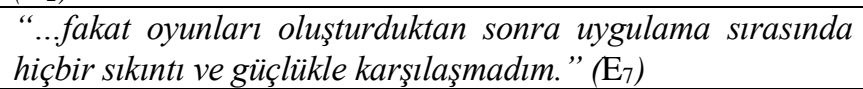 \\
\hline
\end{tabular}

ÖAK: Öğretmen Adayının Kodu

Genel olarak uygulamada yaşanan güçlükler değerlendirildiğinde uygulama yapılan sınıftaki öğrencilerin ilk uygulamalarda adaptasyon sorunu yaşadıkları, ancak zamanla uygulamaların artması ile bu sorunun ortadan kalktığı anlaşılmaktadır.

Tablo 5' te görüldüğü üzere, $\mathrm{K}_{1}$ oyunla öğretimin bazı olumsuz yönlerinin olduğunu ifade ederken özellikle oyunun ders saati içinde tamamlanamayacağını belirtmektedir. Ayrıca, grupla oynanan oyunlarda öğrenciler arasında anlaşmazlıklar çıkabileceğini bu olumsuzluğun da öğretmenin gayreti ile giderilebileceğini ifade etmektedir. Bunun için $\mathrm{K}_{1}$ özellikle grup üyeleri arasındaki işbirliğinin sağlanması gerektiği şeklinde bir öneri sunmuştur. $E_{5}$ oyunla öğretimin sınırlılıklarının olabileceğini belirtirken her oyunun her öğrenci için ilginç olmayabileceğine ve aynı oyunların sürekli oynatılmasının zamanla öğrencileri sıkabileceğini ifade etmiştir. Ayrıca $E_{5}$, oyunun nasıl oynanması gerektiğinin ve oyunun kurallarının öğretmen tarafından iyi açıklanması gerektiğini aksi taktirde öğrenciler için oyunun bir anlamının olmayacağını belirtmiştir. İki öğretmen adayı da $\left(\mathrm{K}_{1}, \mathrm{~K}_{3}\right) \mathrm{E}_{6}$ gibi oyunun oynanması için ders saati süresinin yeterli olmadığını ifade ederken bu olumsuzluğun giderilmesi yönünde $\mathrm{K}_{3}$, oyunların ders saatlerin dışında oynatılabileceği önerisini yapmaktadır. $K_{3}$ ’ün oyunları derslerinde öğretmen olduğunda sıklıkla kullanmayacağını sadece gerekli durumlarda kullanacağını ifade eden önceki açıklamaları ile bu önerisi ile paralellik göstermektedir. 
Usta, N., ve Diğerleri (2017). The opinions of pre-service teachers on the usage of games in mathematics teaching. International Journal of Social Sciences and Education Research, 3(1), 328-344.

Tablo 5. Öğretmen adaylarının oyunlarla matematik öğretiminin olumsuz yönlerinin olması durumuna ilişkin görüşleri

\begin{tabular}{|c|c|c|c|}
\hline Kategori & Alt Kategori & $\begin{array}{c}\ddot{\text { ÖA }} \\
\mathbf{K}\end{array}$ & Örnek Açıklamalar \\
\hline 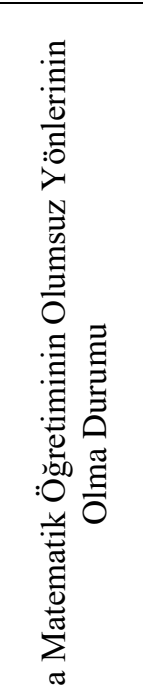 & $\begin{array}{c}\text { Olumsuz Yönleri- } \\
\text { nin Olması }\end{array}$ & $\begin{array}{l}\mathrm{K}_{1}, \\
\mathrm{~K}_{2}, \\
\mathrm{~K}_{3}, \\
\mathrm{~K}_{4}, \\
\mathrm{E}_{5}, \\
\mathrm{E}_{6}\end{array}$ & 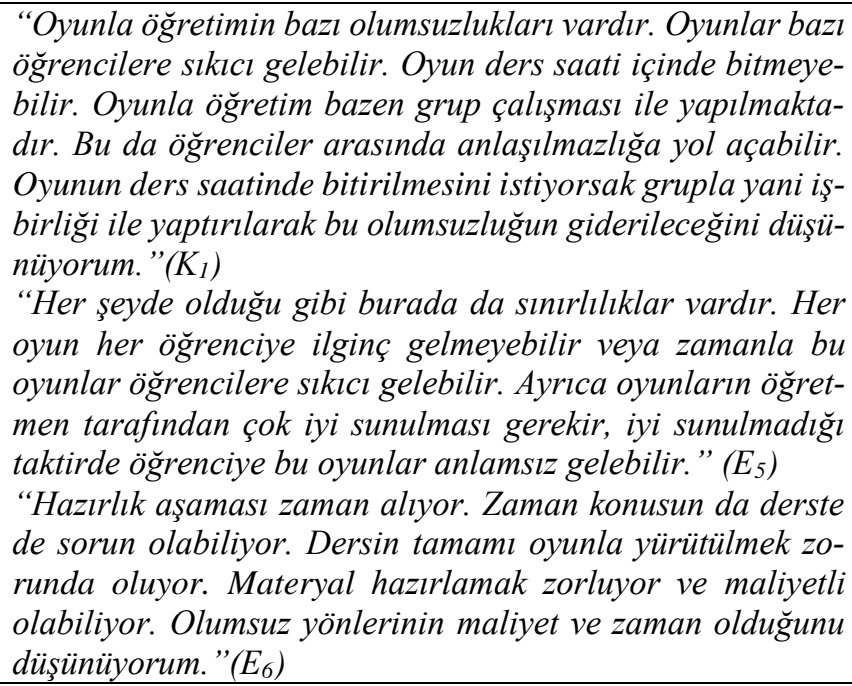 \\
\hline 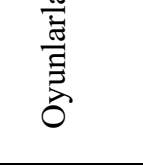 & $\begin{array}{l}\text { Olumsuz Yönleri- } \\
\text { nin Olmaması }\end{array}$ & $\mathrm{E}_{7}$ & $\begin{array}{l}\text { "Oyunlarla ögretimin olumsuz bir tarafi yok fakat kalabalık } \\
\text { sinıflarda sınıf kontrolü biraz zor olabilir. Öğrencilerin se- } \\
\text { viyesi de çok önemli, oyunları uygulama konusunda ögren- } \\
\text { cilere ön bilgiler verirken çok dikkat edilmelidir." }\left(E_{7}\right)\end{array}$ \\
\hline
\end{tabular}

ÖAK: Öğretmen Adayının Kodu

Oyunla öğretimin olumsuz yönlerinin olup olmadığına ilişkin öğretmen adaylarının görüşlerinden elde edilen bulgular değerlendirildiğinde $E_{7}$ dışındaki öğretmen adayları oyunla öğretimin olumsuz yönlerinin olduğunu ifade etmektedirler. $\mathrm{Bu}$ olumsuzluklar arasında ilk sırada sürenin yetersiz olması, öğretim materyali hazırlamanın zorluğu, öğretim materyalinin maliyetinin yüksek olması, kalabalık sınıflarda uygulamanın güç olduğu ve oyunların kurallarının yeterli derecede açıklanamamasından kaynaklanan sıkıntılar gelmektedir.

Altıncı soruda öğretmen adaylarına Ortaokul Matematik Dersi Öğretim Programı (2013)’nda yer alan konuların tamamı ile ilgili olarak oyunla öğretimin yapılıp yapılamayacağı sorulmuş ve cevaplarını gerekçeleri ile açıklamaları istenmiştir. Örnek açıklamaların verildiği Tablo 6'daki bulgular değerlendirildiğinde dört adayın $\left(\mathrm{K}_{2}, \mathrm{E}_{5}, \mathrm{E}_{6}, \mathrm{E}_{7}\right)$ bütün konularda oyunla öğretimin yap1labileceğini düşündüğü üç aday $\left(\mathrm{K}_{1}, \mathrm{~K}_{3}, \mathrm{~K}_{4}\right)$ ise aksini düşündüğü görülmektedir.

$\mathrm{K}_{1}$, oyunla öğretimin programda yer alan bütün konulara uygulanamayacağını düşünmesinin gerekçesi olarak öncelikle her konu ile ilgili materyal hazırlamanın zorluğunu göstermiştir. Ayrıca $\mathrm{K}_{1}$, oyunu hazırlamada ve sinıf içinde uygulamada ders süresinin yeterli olmayacağını ve oyunları matematik dersine uyarlamanın zor olduğunu belirtmektedir. Diğer bir öğretmen adayı $\mathrm{K}_{3}$, özellikle cebir, dönüşüm geometrisi ve trigonometri konularında oyun hazırlamanın güçlügünden bahsederek bütün konularda oyunla öğretimin yapılamayacağını düşündüğünü ifade etmiştir. $\mathrm{K}_{4}$ ise, matematik dersi gibi soyut bir dersin ancak belli ölçülerde somutlaştırılabileceğini düşündüğünden oyunla öğretimin her konuda yapılamayacağını ve her konuda yapılacak oyunla öğretimin öğretmen ve öğrenciler için zahmetli olacağını ifade etmiştir. Öğretmen adayının oyunun hazırlanması sırasında yaşanan güçlüklerden ve zamanın etkili kullanılamamasından dolayı bu şekilde düşündügü söylenebilir. Olumlu görüş belirten diğer öğretmen adayları ise gerekli zaman ve emek harcandığında her konuda oyun hazırlanabileceği ve oyunla öğretimin yapılabile- 
Usta, N., ve Diğerleri (2017). Öğretmen adaylarının matematik öğretiminde oyunların kullanımı ile ilgili görüşleri. International Journal of Social Sciences and Education Research, 3(1), 328-344.

ceğini düşündüklerini belirtmiştir. Adaylar sınıf seviyesinin ve konunun gerektirdiği kazanımların dikkate alınmasıyla hazırlanacak oyunların uygulanabileceğini $\left(\mathrm{E}_{7}, \mathrm{~K}_{2}\right)$ düşünmektedirler. Ayrıca öğrencilerin tamamının aktif bir şekilde katılımını sağlayan $\left(E_{6}\right)$ bir süreci gerçekleştirmesinden dolayı oyunla öğretimin programda yer alan her konuda ve sınıf seviyesinde yapılabileceğini düşündüklerini ifade etmektedirler.

Tablo 6. Öğretmen adaylarının ortaokul matematik dersi öğretim programında yer alan bütün konularda oyunla öğretimin yapılabilir olma durumuna ilişkin görüşleri

\begin{tabular}{|c|c|c|c|}
\hline Kategori & Alt Kategori & $\begin{array}{l}\text { ÖA } \\
\text { K }\end{array}$ & Örnek Açıklamalar \\
\hline 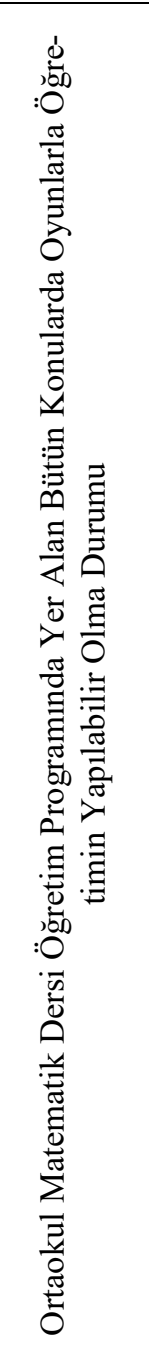 & Olumsuz Görüş & $\begin{array}{l}\mathrm{K}_{2}, \\
\mathrm{E}_{5}, \\
\mathrm{E}_{6}, \\
\mathrm{E}_{7}\end{array}$ & 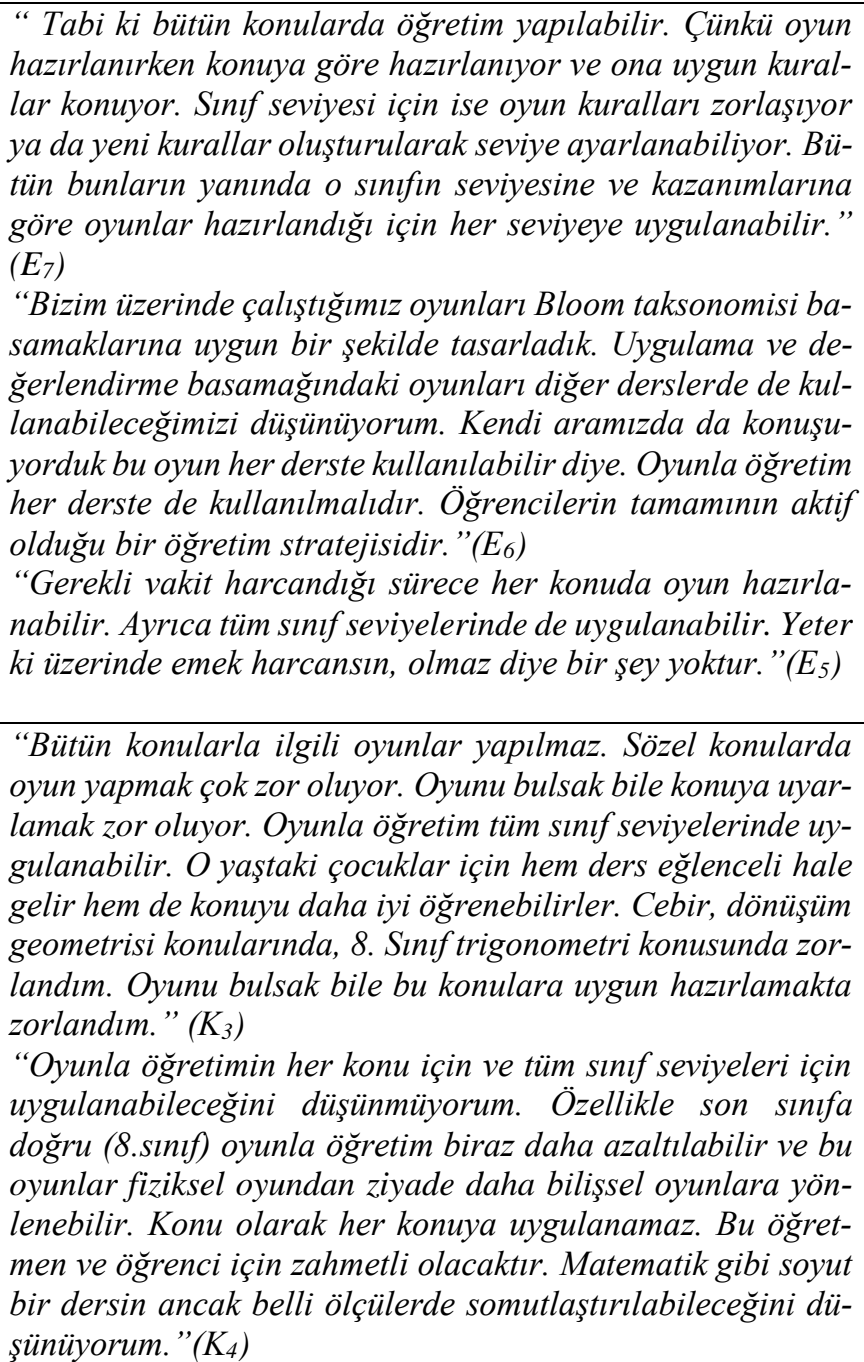 \\
\hline
\end{tabular}

ÖAK: Öğretmen Adayının Kodu 
Usta, N., ve Diğerleri (2017). The opinions of pre-service teachers on the usage of games in mathematics teaching. International Journal of Social Sciences and Education Research, 3(1), 328-344.

Tablo 7. Öğretmen adaylarının uygulama ve uygulama sürecine ilişkin görüşleri

\begin{tabular}{|c|c|c|c|}
\hline Kategori & Alt Kategori & ÖAK & Örnek Açıklamalar \\
\hline \multirow{10}{*}{ 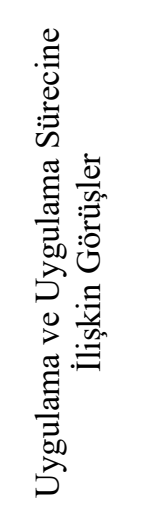 } & \multirow{9}{*}{ Olumlu Görüş } & \multirow{9}{*}{$\begin{array}{l}\mathrm{K}_{2}, \\
\mathrm{~K}_{3}, \\
\mathrm{~K}_{4}, \\
\mathrm{E}_{5}, \\
\mathrm{E}_{6}, \\
\mathrm{E}_{7}\end{array}$} & "Projeyi pilot okulda uyguladığımızda öğrencilerin çok is- \\
\hline & & & tekli olduğunu gördüm ve sinıfta derslerinde başarılı olma- \\
\hline & & & yan ögrencilerin bile aktif şekilde derse katıldıklarını, konu \\
\hline & & & $\begin{array}{l}\text { hakkında bilgi sahibi olduklarını fark ettim. Bazl ogrencile- } \\
\text { rin artık matematiği seviyorum dediklerini duydum." }\left(E_{7}\right)\end{array}$ \\
\hline & & & "Okuldaki uygulamalara bizzat şahit oldum, süreç çok iyi \\
\hline & & & ilerledi ve ögrencilerden çok güzel dönütler aldım, bu proje \\
\hline & & & hem ögretmenlerin dersteki yüklerini hafifletecek hem de öğ- \\
\hline & & & $\begin{array}{l}\text { rencilerin anlamlı, eğlenceli öğrenmelerine yardımcı ola- } \\
\text { caktır." }\left(E_{5}\right)\end{array}$ \\
\hline & & & $\begin{array}{l}\text { "Matematik eğitimine farklı bir açıdan yaklaştı̆̆ımızı ve eği- } \\
\text { timimizi zenginleştirdiğimizi düşünüyorum." }\left(K_{4}\right)\end{array}$ \\
\hline & Olumsuz Görüş & - & - \\
\hline
\end{tabular}

ÖAK: Öğretmen Adayının Kodu

Yedinci soruda öğretmen adaylarına bu çalışma boyunca yapılan uygulamalar ve süreçte yaşadıklarına ilişkin eklemek istedikleri başka görüşlerinin olup olmadığı sorulmuş ve elde edilen bulgular analiz edilmiştir. Tablo 7'de örnek açıklamalar verilmektedir. Buna göre, $\mathrm{K}_{1}$ dışındaki altı aday uygulamaların ve süreç içinde yaptıklarının çok faydalı olduğunu, matematik eğitimine yönelik olarak farklı bir bakış açısı kazandırdığını ve eğitimlerini zenginleştirdiğini, oyunla öğretimin öğrenciler üzerinde olumlu etkiler bırakarak matematiği sevdirdiğini ifade etmektedirler. Ayrıca öğretmen adayları bu uygulamanın alan bilgilerinin gelişimine katkı sağladığını, oyun hazırlamayı ve oyun hazırlamanın güçlüklerinin neler olabileceğini öğrendiklerini ve yapılan bu çalışmanın ortaokul öğrencilerine matematik dersini sevmelerine katkı sağlayacağını düşündüklerini belirtmişlerdir. $\mathrm{K}_{1}$, uygulama ve süreci hakkında olumlu ya da olumsuz herhangi bir görüş belirtmemiştir.

\section{Sonuç, tartışma ve öneriler}

$\mathrm{Bu}$ çalışmada ortaokul matematik öğretmeni adaylarının matematik öğretiminde oyunların kullanımına ilişkin görüşleri incelenmiştir. Çalışmadan elde edilen bulgulara dayanarak, öğretmen adaylarının matematik derslerinde oyunların kullanılmasının gerekli ve yararlı olduğunu düşündükleri ortaya çıkmıştır. Öğretmen adayları bu şekilde düşünmelerinin gerekçelerini ise oyun ile matematik dersinin birleştirilerek eğlenceli bir şekilde sunulması ve öğrencinin derse aktif katılımını sağlaması olarak ortaya koymuşlardır. Öğretmen adaylarının bu görüşleri Kaya ve Elgün (2015)' in çalışmalarında elde ettikleri sonuçlar ile örtüşmektedir. Kaya ve Elgün (2015) uyguladıkları eğitsel oyunların öğrencilerin zihinsel ve fiziksel olarak derse aktif olarak katılımlarını sağladığını ortaya koymuşlardır. Öğretmen adayları eğlenceli öğretim ortamlarında matematik dersinin somut materyallerle ve anlaşılır olarak sunulmasıyla öğrencinin matematik dersine karşı olan korku ve kaygısının azaltılabileceğini düşünmektedirler. Adayların bu görüşünü destekleyen matematik derslerinde oyunların kullanıldığ böylece öğrencilerin derse karşı olan ilgilerinde ve tutumlarında olumlu yönde değişmelerin olduğunu gösteren çalışmalar (Aksoy \& Kaleli Yılmaz, 2011; Gelen \& Özer, 2010; Katmada, Mavridis, \& Tsiatso, 2014; Şaşmaz Ören \& Erduran Avc1, 2004; Tural, 2005; Tural Sönmez, 2012) bulunmaktadır.

Öğretmen adaylarının oyun hazırlama aşamasında yaşadıkları güçlüklere ilişkin bulgulara dayalı olarak elde edilen sonuçlara göre genel olarak adaylar her konuya ve her kazanıma göre oyun hazırlamada ve oyunun kurallarının oluşturulmasında zorluklar yaşadıklarını ifade etmişlerdir. 
Usta, N., ve Diğerleri (2017). Öğretmen adaylarının matematik öğretiminde oyunların kullanımı ile ilgili görüşleri. International Journal of Social Sciences and Education Research, 3(1), 328-344.

Oyunda kullanılacak materyallerin hazırlanmasında özellikle bazı oyunlardaki materyallerin hazırlanması el becerisi gerektirdiğinden zorlandıklarını ve bundan dolayı oyun hazırlamanın maliyetinin arttığını belirtmişlerdir. Benzer bir durum Güneş (2010)'in çalışmasında oyun hazırlamanın ekonomik olarak yük getireceğini ifade eden matematik öğretmenlerinin görüşleri ile paralellik göstermektedir.

Öğretmen adaylarının hazırlanan oyunların sınıf ortamında uygulanması aşamasında yaşadıkları güçlüklere ilişkin bulgulara dayalı olarak öğretmen adayları ilk uygulamalarda öğrencilerin oyunlarla öğretim yöntemine karşı bir adaptasyon sorunu yaşadıklarını ancak uygulamaların artmasıyla bu sorunun ortadan kalktığını belirtmişlerdir. Ayrıca öğretmen adayları uygulamalar sırasında zaman yönetimi ve sınıf kontrolü konusunda bazı sıkıntılar yaşadıklarını da dile getirmişlerdir. $\mathrm{Bu}$ sonuç, Güneş (2010)'nun çalışmasının sonuçları ile örtüşmektedir. Öğretmen adaylarının bu konuda yaşadıkların sıkıntıların mesleki tecrübelerinin olmamasından kaynaklandığı düşünülebilir.

Öğretmen adaylarının oyunla öğretimin olumsuz yönlerinin olup olmaması ile ilgili görüşlerine ilişkin bulgulara dayalı olarak elde edilen sonuçlara göre bir öğretmen adayı dışında diğer adaylar oyunla öğretimin olumsuz yönlerinin olabileceğini ifade etmişlerdir. Bu olumsuzluklar arasında oyunla öğretimin çok zaman almasından dolayı ders süresinin yeterli olmaması bulunmaktadır. Bazı öğretmen adayları bu olumsuzluğunun giderilmesi yönünde oyunların ders saatleri dışında oynatılabileceği şeklinde öneriler sunmuşlardır. Bazı öğretmen adayları ise oyunların derse giriş aşamasında veya konudan sonra pekiştirme yapılması amacıyla veya dikkat çekmek amacıyla kullanılmasının daha uygun olacağı yönünde görüşler belirtmişlerdir. Bu görüşler Güneş (2010)' in çalışmasının sonuçları ile paralellik göstermektedir. Ayrıca sürekli oyunla öğretimin yapılmasının öğrencileri sıkabileceğini ve öğrencilerin bu duruma alışacaklarından dolayı ilgilerinin azalabileceğini düşündüklerini belirtmişlerdir. Öğretmen adaylarının üzerinde durduğu diğer bir olumsuzluk ise öğretim materyali hazırlamanın zorluğu ve maliyetli olmasıdır. Öğretmen adayları oyunla öğretimin kalabalık sınıflarda uygulamanın güç olabileceğini düşündüklerini ifade etmişlerdir. Öğretmenin yöntem hakkında yeterince bilgi sahibi olması ve tecrübesinin de yeterli olması yöntemin başarısı için önemli bulunmaktadır. Oyunun nasıl oynanacağı, oyun sırasında sınıfın durumu, öğrenciler arası ilişkilerin düzenlenmesi, oyunun öğrenciler tarafından anlaşıldığından emin olunması ve oyunun süresi, oyunun kuralları gibi önemli başlıkların öğretmen tarafından çok iyi açıklanması ve uygulanması gerekmektedir. Aksi taktirde öğretmen adaylarına göre matematik öğretiminde oyunların kullanılması zaman kaybından başka bir şey değildir. Güneş (2010) öğretmenlerin görüşlerini incelediği çalışmasında öğretmenin tecrübesinin yetersiz olması durumunda çeşitli zorlukların yaşanabileceğini, oyun ve etkinliklerin öğretmene fazladan sorumluluk yükleyeceğini, ekonomik olarak yük getireceğini, sınıf mevcutlarının fazla olmasının yöntemi olumsuz yönde etkileyeceğini ve sınıf yönetiminde çeşitli zorlukların yaşanabileceği şeklinde bazı olumsuzluklar dile getirdikleri ifade edilmiştir.

Öğretmen adaylarının öğretim programında yer alan bütün konularda ve bütün sınıf seviyelerinde matematiksel oyunların hazırlanıp hazırlanmayacağı konusundaki görüşlerine ilişkin bulgulara dayalı olarak elde edilen sonuçlara göre bazı öğretmen adayları her konuda oyun hazırlamanın güç olduğunu özellikle cebir, dönüşüm geometrisi ve trigonometri konularında zorlandıklarını ifade etmişlerdir. Bazı öğretmen adayları da her konuda oyun hazırlamanın öğretmene fazladan yük getireceğine inandıklarını belirtmişlerdir. Benzer bir durum Uğurel (2003)'in çalışmasında öğretmenlerin uygulanan matematik programının çok yoğun olmasından dolayı öğretimde 
Usta, N., ve Diğerleri (2017). The opinions of pre-service teachers on the usage of games in mathematics teaching. International Journal of Social Sciences and Education Research, 3(1), 328-344.

farklı aktivitelere yer veremediklerini ifade eden görüşleri ile paralellik göstermektedir. Bazı öğretmen adayları ise yeterli zamanın ve emeğin harcanmasıyla istenilen her konuda ve bütün sınıf seviyelerine göre oyunların hazırlanabileceğini ifade etmişlerdir. Bunun gerekçesini de oyunların ve oyunun kurallarının programdaki konuların kazanımlarının dikkate alınarak hazırlanması olarak göstermişlerdir.

Öğretmen adaylarının öğretmen olduklarında matematik derslerinde oyunlarla öğretimi yapmaları veya yapmamalarının nedenlerine ilişkin bulgulara dayalı olarak elde edilen sonuçlara göre öğretmen adayları oyunların matematik dersini daha zevkli, eğlenceli ve anlaşılır hale getirdiği ve verimli bir öğrenme ortamı oluşturduğu için oyunları derslerinde kullanacaklarını belirtmişlerdir. Öğretmen adaylarının bu görüşleri Tural (2005) ve Uğurel (2003) tarafından yapılan çalışmalarla da desteklenmektedir. Tural (2005)'e göre oyun ve etkinliklerle öğretim, öğrenme ortamını somut, görsel ve işitsel pek çok materyal ile zenginleştirerek dersi daha zevkli ve eğlenceli hale getirmektedir. $\mathrm{Bu}$ durum öğrencilerin derse olan tutumlarını olumlu yönde etkilemektedir. Ayrıca oyunlarla öğretimin öğrencilerin derse olan tutumlarında etkili olmasının nedenleri arasında oyunların derse ve konuya ilgiyi sürekli hale getirmesi, öğrencileri aktif hale getirmesi ve öğrenciler arasındaki iletişimi arttırması yer almaktadır. Uğurel (2003) öğretmenlerin ve öğretmen adaylarının oyunla öğretim hakkındaki görüşlerini değerlendirdiği çalışmasında, oyunların öğrencilerin derse olan ilgilerini arttırdığı motivasyonu ve eğlenerek öğrenmeyi sağladığı, öğretmen-öğrenci ve öğrenci-öğrenci arasındaki iletişimi sağlıklı bir şekilde kurduğunu ifade eden görüşlere yer vermiş̧ir.

Ancak bazı öğretmen adayları matematiksel oyunları öğrencilerin dikkatini çekmek, konuya giriş yapmak, konuları pekiştirmek ve farklı bir yöntem uygulamak amacıyla kullanacağını belirtirken diğer öğretmen adayları ise anlatmakta güçlük yaşayacağını düşündüğü konuların mantığını kavratmak amacıyla ve dersi daha etkili ve verimli hale getirmek için her zaman kullanacaklarını ifade etmişlerdir. Bazı öğretmen adaylarının oyunu konuyu pekiştirmek amacıyla kullanma yönündeki görüşü Altun (2014)'un oyunların bilginin kazanılması sonrasında konunun pekiştirilmesi amacıyla kullanılması gerektiği yönündeki görüşüyle desteklenmektedir.

Öğretmen adaylarına son olarak uygulamalar sırasında ve süreç boyunca yaşadıkları ile ilgili olarak eklemek istedikleri herhangi bir görüşlerinin olup olmadığı sorulmuştur. Elde edilen bulgulara dayalı olarak yedi öğretmen adayından bir aday herhangi bir görüş belirtmezken diğerleri süreç içinde yaptıklarının çok faydalı olduğunu ve matematik eğitimine yönelik olarak farklı bir bakış açısı kazandıklarını ve eğitimlerini zenginleştirdiğini düşündüklerini ifade etmişlerdir. Ayrıca öğretmen adayları bu uygulamanın alan bilgilerinin gelişimine katkı sağladığını, oyun hazırlamayı ve oyun hazırlamanın güçlüklerinin neler olabileceğini öğrendiklerini ve yapılan bu çalışmanın ortaokul öğrencilerine matematik dersini sevmelerine katkı sağlayacağını düşündüklerini belirtmişlerdir.

Matematik öğretiminde oyunların kullanılmasına ilişkin öğretmen adaylarının görüşlerinin incelendiği bu çalışmadan çıkan sonuçlara göre bazı öneriler getirilebilir. Öğretmen adaylarına Oyunlarla Matematik Öğretimi, Özel Öğretim Yöntemleri I-II ve Öğretim Teknolojileri ve Materyal Geliştirme gibi lisans derslerinde oyunların matematik öğretimi üzerindeki önemine değinilerek öğretim programı içeriğindeki konulara yönelik olarak oyunların araştırılması, hazırlanması, yazılması ve uygulanması konuları üzerinde detaylı bir şekilde durulabilir. İkinci olarak bu çalışma öğretmen adaylarının yazılı açıklamalarıyla ve görüşme tekniği ile sınırlıdır. İleride yapılacak çalışmalar için gözlem tekniğinin birlikte kullanılmasıyla daha detaylı veriler elde edilebilir. 
Usta, N., ve Diğerleri (2017). Öğretmen adaylarının matematik öğretiminde oyunların kullanımı ile ilgili görüşleri. International Journal of Social Sciences and Education Research, 3(1), 328-344.

\section{Kaynakça}

Aksoy, N.C. \& Kaleli-Yılmaz, G. (2011). Kesirler konusunda uygulanan oyun destekli öğretimin altınc1 sınıf öğrencilerinin matematiğe yönelik tutumlarına etkisi. Bayburt Üniversitesi Eğitim Fakültesi Dergisi, 6(I-II), 105-117.

Charles, M., Bustard, D., \& Black, M. (2009). Experiences of promoting engagement in game-based learning. Proceedings of the European Conference on Games Based Learning, 397-403. Retrieved from Education Research Complete database.

Duran, M. \& Kaplan, A. (2014). Matematiksel kavramlarla geliştirilen 'kelimeden kavrama' oyununa ilişkin öğrenci-öğretmen görüşleri. Ahi Evran Üniversitesi Kırşehir Eğitim Fakültesi Dergisi, 15(2). 155173.

Gelen, İ. \& Özer, B. (2010). Oyunlaştırmanın beşinci sınıf matematik dersinde problem çözme becerisi ve derse karş1 tutum üzerindeki etkisi. e- Journal of New World Sciences Academy. 5(1). 71-87.

Güneş, G. (2010). Illköğretim ikinci kademe matematik öğretiminde oyun ve etkinliklerin kullanımına ilişkin öğretmen görüşleri (kars ili örneği). Yayınlanmamış Yüksek Lisans Tezi. Kafkas Üniversitesi, Sosyal Bilimler Enstitüsü. Kars.

Hays, R.T.(2005).The effectiveness of instructional games: a literature review and discussion.

Retrieved17.11.16from. http://faculty.uoit.ca/kapralos/csci5530/Papers/hays instructionalGames.pdf

Katmada, A., Mavridis, A., \& Tsiatsos, T. (2014). Implementing a gam efor supporting learning in mathematicss. The Electronic Journal of e-Learning, 12(3), 230-242.

Kaya, S. \& Elgün, A. (2015). Eğitsel oyunlar ile desteklenmiş fen öğretiminin ilkokul öğrencilerinin akademik başarısına etkisi. Kastamonu Ĕ̆itim Dergisi. 23(1), 329-342.

Köroğlu, H. \& Yeşildere, S. (2002). İlköğretim II. Kademede matematik konularının öğretiminde oyunlar ve senaryolar. V. Ulusal Fen Bilimleri ve Matematik Eğitimi Kongresi, Ankara, ODTÜ Kültür ve Kongre Merkezi, 2002. (int.erişim tarihi. 27.10.2016).

Lee, Y.L. (2008). Enhancement of fractions from playing a game. Universitiy of Otago. Retrieved 23.11.16 from.

Malone, T. W. (1980). What makes things fun to learn? A studuy of intrinsically motivating çomputer games. Technical report, Xerox Palo Alto Research Center, Palo Alto, California. İnternet erişim tarihi: 23.11.2016.

Özgenç, N. (2010). Oyun temelli matematik etkinlikleriyle yürütülen ögrenme ortamlarından yansımalar. Yayınlanmamış Yüksek Lisans Tezi. Karadeniz Teknik Üniversitesi, Fen Bilimleri Enstitüsü, Trabzon.

Prince, M. (2004). Does active learning work? A review of the research. Journal of Engr. Education, 93(3), 223-231. Departmant of Chemical Engineering Bucknell University.

Randel, J. M. \& Morris, B. A. (1992). The Effectiveness of games for educational purposes: A Review of Recent Research., Simulation \& Gaming, 23(3).

Şaşmaz Ören, F. \& Erduran Avcı, D. (2004). Eğitimsel oyunla öğretimin fen bilgisi dersi "güneş sistemi ve gezegenler” konusundaki akademik başarı üzerine etkisi. Ondokuz Mayıs Üniversitesi Eğitimi Fakültesi Dergisi, 18(2004), 67-76.

Tural, H. (2005). Illköğretim matematik ögretiminde oyun ve etkinliklerle öğretimin erişi ve tutuma etkisi. Yayınlanmamış Yüksek Lisans Tezi. D.E.Ü., Eğitim Bilimleri Enstitüsü, İzmir.

Tural Sönmez, M. (2012). 6. Sinıf matematik derslerinde web üzerinden sunulan eğitsel matematik oyunlarının öğrenci başarısına etkisi. Yayımlanmamış Yüksek Lisans Tezi. Çukurova Üniversitesi, Sosyal Bilimler Enstitüsü, Adana.

Uğurel, I. (2003). Ortä̈gretimde oyunlar ve etkinlikler ile matematik ögrretimine ilişkin öğretmen adayları ve ögretmenlerin görüşleri. Yayınlanmamış Yüksek Lisans Tezi. D.E.Ü., Eğitim Bilimleri Enstitüsü, İzmir.

Yıldırım, A. \& Şimşek, H. (2008). Sosyal bilimlerde nitel araştırma yöntemleri (7. baskı)., Ankara: Seçkin Yayinlar1. 
Usta, N., ve Diğerleri (2017). The opinions of pre-service teachers on the usage of games in mathematics teach-

ing. International Journal of Social Sciences and Education Research, 3(1), 328-344.

\section{Extended abstract in English}

Teaching with games is an effective method in the acquisition of mathematical abilities, in the development of positive attitudes towards mathematics in students (cited from Soylu, 2001 by Tural, 2005), in the concretization of the mathematics course and in the acquisition of the concepts (Altunay, 2004). Games are considered as one of the useful activities in mathematics teaching (Lovitt \& Clarke, 1988, cited by. Lee, 2008). According to Foster, "The best way to incorporate students into mathematics activities is to ensure the establishment of a bond by them between the games and their own worlds" (cited by. Uluçay and Çakır, 2004).

The fact that the games appeal to more than one sense organ during the process of teaching with games, the preparation of games with concrete materials and the fact that they promote communication between students are important (Kaya \& Elgün, 2015). According to Charles, Bustard and Black (2009), success increases as the participation in learning environment increases. One of the best ways to ensure active participation is to use educational games. One of the most important benefits of using games in the learning process is the provision of an amusing learning environment by providing integrity with teaching objectives (Hays, 2005). In this study, primary school mathematics preservice teachers' opinions about the use of games in mathematics teaching are examined. When the literature is examined, there are studies examining the opinions of secondary school teachers and preservice teachers (Ugurel, 2003) and teachers in the primary school second level (Güneş, 2010) about the use of games and activities in mathematics teaching. However, there were not many studies examining the opinions of primary school mathematics preservice teachers about the use of games in mathematics teaching. Accordingly, it was aimed to examine the opinions of preservice teachers about the use of games in mathematics teaching in the study.

The case study method based on the qualitative research approach was used in the study.

7 fourth-grade students studying at the Department of Elementary Mathematics Teaching of a state university located in a province of the Western Black Sea Region constituted the participants of this study. Preservice teachers took the courses of "Special Teaching Methods I", "Special Teaching Methods II", which are undergraduate courses, and "Mathematics Teaching with Games", which is a postgraduate course, during two terms. For two years, preservice teachers prepared games on various subjects included in the Secondary School Mathematics Course Curriculum (2013). The games prepared regarding the subjects of percentages, lines, and angles, polygons and circle and closed disc were applied to students studying in 7th grade of a state school along with the course teachers continuing their postgraduate education and preservice teachers for 2 months in the 2015-2016 academic year. At the end of the applications, preservice teachers' opinions about the use of games in mathematics teaching were received. In the study, codes in the form of $\mathrm{K}_{1}, \mathrm{~K}_{2}, \mathrm{~K}_{3}, \mathrm{~K}_{4}, \mathrm{E}_{5}, \mathrm{E}_{6}$ and $\mathrm{E}_{7}, \mathrm{~K}$ for female students and $\mathrm{E}$ for male students, were provided instead of the actual names of preservice teachers.

The semi-structured interview form consisting of 7 open-ended questions which was prepared by researchers in line with the expert opinions was used as a data collection tool. In the interview form, preservice teachers were asked about their opinions on teaching mathematics with games, difficulties they encountered while preparing game and whether they had difficulties, in which subject they had difficulty if they had difficulty, whether teaching with game could be performed in all subjects in the curriculum, whether this method would be applied at every grade level in secondary school, whether teaching with game has any negative aspects, and what those aspects 
Usta, N., ve Diğerleri (2017). Öğretmen adaylarının matematik öğretiminde oyunların kullanımı ile ilgili görüşleri. International Journal of Social Sciences and Education Research, 3(1), 328-344.

are if any. In addition, preservice teachers were asked about whether they think to use teaching with games method in mathematics courses when they become a teacher, and finally if there is anything else they would like to add.

The analysis of the data was performed by the content analysis, one of the qualitative data analysis techniques. The data obtained from this study were separated into categories and subcategories by the researchers, and the coding percentage was found to be $85 \%$. The researchers came together for the difference and reached consensus.

Based on the findings obtained from the study, it has been revealed that preservice teachers think that the use of games in mathematics courses is necessary and useful. Preservice teachers showed the presentation of mathematics courses in an amusing way by combining with games and ensuring the active participation of the student in the course as the reasons for this way of thinking. These opinions of preservice teachers are in line with the results obtained in the study of Kaya and Elgün (2015). Preservice teachers think that the fear and anxiety of the student about the mathematics lesson can be reduced by the presentation of mathematics course with concrete materials in a comprehensible way in amusing learning environments. There are studies (Aksoy \& Kaleli Y1lmaz, 2011; Gelen \& Özer, 2010; Katmada, Mavridis, \& Tsiatso, 2014; Şaşmaz Ören \& Erduran Avc1, 2004; Tural, 2005; Tural Sönmez, 2012) supporting this opinion of preservice teachers and indicating that games are used in mathematics courses and thus positive changes occur in students' attitudes and interests in courses.

Some suggestions can be made according to the results of this study in which preservice teachers' opinions about the use of games in mathematics teaching are examined. The issues of investigating, preparing, writing and applying games for the subjects included in the curriculum can be elaborated in detail by addressing the importance of games on mathematics teaching in undergraduate courses such as Mathematics Teaching with Games, Special Teaching Methods I-II and Teaching Technologies and Material Development for preservice teachers. Secondly, this study is limited to the written statements of preservice teachers and the interview technique. More detailed data can be obtained by using the observation technique together for further studies. 